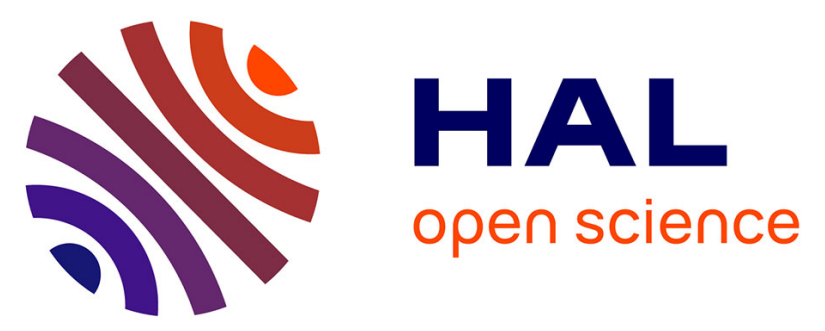

\title{
Colonic luminal proteases activate colonocyte proteinase-activated receptor-2 and regulate paracellular permeability in mice
}

R. Róka, Julien Demaude, N. Cenac, Laurent Ferrier, Christel Cartier, Rafael Garcia Villar, Jean Fioramonti, Lionel Bueno

\section{To cite this version:}

R. Róka, Julien Demaude, N. Cenac, Laurent Ferrier, Christel Cartier, et al.. Colonic luminal proteases activate colonocyte proteinase-activated receptor-2 and regulate paracellular permeability in mice. Neurogastroenterology \& Motility, 2007, 19 (1), pp.57-65. 10.1111/j.1365-2982.2006.00851.x . hal01562302

\section{HAL Id: hal-01562302 \\ https://hal.science/hal-01562302}

Submitted on 13 Jul 2017

HAL is a multi-disciplinary open access archive for the deposit and dissemination of scientific research documents, whether they are published or not. The documents may come from teaching and research institutions in France or abroad, or from public or private research centers.
L'archive ouverte pluridisciplinaire HAL, est destinée au dépôt et à la diffusion de documents scientifiques de niveau recherche, publiés ou non, émanant des établissements d'enseignement et de recherche français ou étrangers, des laboratoires publics ou privés.

\section{다(1)(2)}

Distributed under a Creative Commons Attribution - ShareAlikel 4.0 International 


\title{
Colonic luminal proteases activate colonocyte proteinase-activated receptor-2 and regulate paracellular permeability in mice
}

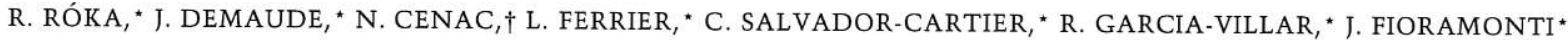 \\ \& L. BUENO* \\ *INRA Neuro-Gastroenterology \& Nutrition Unit, Toulouse, France \\ $\dagger$ Department of Pharmacology and Pharmacotherapy, University of Calgary, AB, Canada
}

\begin{abstract}
Luminal activation of protease-activated receptors-2 $\left(P A R_{2}\right)$ on colonocytes by trypsin or $P A R_{2}-$ activating peptide increases colonic paracellular permeability (CPP). The aim of this study was to evaluate the role of proteases from endogenous and bacterial origin in the modulation of CPP and colonocyte $P A R_{2}$ expression in mice. CPP was assessed with ${ }^{51} \mathrm{Cr}$-EDTA after intracolonic administration of different protease inhibitors. After 12 days of oral antibiotic treatment, measurements of colonic luminal serine protease activity (CLSPA), CPP, mucosal mouse mast cell proteinase-1 (MMCP-1) content, immunochemistry of $P A R_{2}$ and assessment of effects of $P A R_{2}$ agonist (SLI$G R L)$ and mast cell degranulator (C48/80) on CPP in Ussing chambers were performed. Immunochemistry was repeated after intracolonic trypsin administration. Colonic infusion of protease inhibitors significantly reduced CPP. In antibiotic-treated mice, CLSPA was reduced coupled with a decrease in $P A R_{2}$ expression, but with no change in CPP and MMCP-1 content. Trypsin administration restored $P A R_{2}$ expression. The increase in CPP induced by SLIGRL and C48/80 was reduced after antibiotic treatment. Protease activity of colonic content plays an important role in the regulation of mucosal barrier through activation of $P A R_{2}$.
\end{abstract}

Keywords antibiotic treatment, colonic paracellular permeability, mouse mast cell proteinase-1, proteaseactivated receptor-2, protease inhibitor, Ussing chamber.

\section{Address for correspondence}

Dr Lionel Bueno, INRA, Neuro-Gastroenterology \& Nutrition Unit, 180 Chemin de Tournefeuille, BP 3, 31931 Toulouse Cedex 9, France.

Tel: +33 56128 5143; fax: +33 56128 5145;

e-mail: lbueno@toulouse.inra.fr

Received: 24 April 2006

Accepted for publication: 18 August 2006

\section{INTRODUCTION}

Protease-activated receptors (PARs) belong to a family of seven transmembrane domain G-protein-coupled receptors that are activated by the cleavage of their $\mathrm{N}$-terminal domain by a proteolytic enzyme. ${ }^{1}$ The unmasked new $\mathrm{N}$-terminal sequence acts as a tethered ligand that binds and activates the receptor itself. PARs are expressed throughout the gastrointestinal tract on several cell types, as enterocytes, mast cells, smooth muscle cells, myenteric neurons and endothelial cells. ${ }^{2}$ Moreover, a preliminary immunohistochemical study indicates that $\mathrm{PAR}_{2}$ are mainly localized on the apical site of colonic epithelial cells. In vivo, intracolonic activation of $\mathrm{PAR}_{2}$ leads to colonic inflammation in mice and increases paracellular permeability with bacterial translocation into peritoneal organs. $\mathrm{PAR}_{2}$ activation results in downregulation of the receptor at the apical sites of colonocytes followed by an upregulation prominently in the intracellular compartments in crypts. ${ }^{3}$ In mice, intracolonic infusion of low-dose $\mathrm{PAR}_{2}$-activating peptide (SLIGRL) increases colonic paracellular permeability (CPP) by a direct myosin-light chain kinase (MLCK)-dependent mechanism. ${ }^{4} \mathrm{PAR}_{2}$ activationinduced colitis is dependent on sensory neuron activation, substance $\mathrm{P}$ and calcitonine gene related peptide release. ${ }^{5,6}$ Overexpression of $\mathrm{PAR}_{2}$ was observed in biopsies from inflammatory bowel disease (IBD) patients, suggesting a pathophysiological role of $\mathrm{PAR}_{2}$ in the development of colonic inflammation. ${ }^{7}$ Recent preliminary works demonstrated an increased trypsin-like proteolytic activity in colonic biopsies from irritable bowel syndrome (IBS) patients. This protease activity was able to cause hyperalgesia when injected into mouse paws thoroughly a mechanism involving $\mathrm{PAR}_{2}$ activation. ${ }^{8}$ In spite of 
growing evidences of the important role of $\mathrm{PAR}_{2}$ in pathological conditions, the physiological role of $\mathrm{PAR}_{2}$ located on colonocytes remains unclear.

Proteases are present in great amount in the gastrointestinal tract. In addition to their digestive role in protein degradation, they play a role as signalling molecules regulating cell functions by cleaving PARs. PARs are activated by a variety of proteases, such as digestive enzymes (trypsin and trypsinogen), proteases released from mast cells and neutrophils, and by proteases of the coagulation cascade. Proteases of human pathogen Porphyromonas gingivalis activate PARs on human oral epithelial cells, neutrophils and platelets. $^{9-11}$ Even though resident colonic bacteria release considerable amount of proteases, no studies have already evaluated the effects of intestinal bacterial flora on PAR activation. All these data let us to hypothesize that bacterial proteases or at least luminal proteases of the cited origins may also act on PARs on colonocytes, and may affect CPP by modulating the degree of $\mathrm{PAR}_{2}$ activation.

The present study is aimed (i) to evaluate if intraluminal proteases and particularly serine proteases play a role in the physiological control of paracellular permeability by infusing intracolonically a mixture or selective protease inhibitors, (ii) to determine more specifically the role of proteases from bacterial origin in the regulation of colonic barrier function and (iii) to assess the role of proteases from mast cells in colonic $\mathrm{PAR}_{2}$ activation.

\section{MATERIALS AND METHODS}

\section{Animals}

Male Swiss 3T3 and C57BL6 mice were obtained from Janvier (Le Genest St-Isle, France). Mice were housed in polycarbonate cages in a light $(12 \mathrm{~h} / 12 \mathrm{~h}$ cycle $)$ - and temperature-controlled room $\left(20-22^{\circ} \mathrm{C}\right)$ and were fed standard pellets (UAR pellets, Epinay, France). Water was provided ad libitum. The experimental protocols described in this study were approved by the local Institutional Animal Care and Use Committee.

\section{Intracolonic injections}

Mice were fasted for $12 \mathrm{~h}$ before intracolonic injections. Under mild xylazine/ketamine $(10$ and $2 \mathrm{mg}$ per mouse, respectively, subcutaneously| anaesthesia, a small polyethylene catheter $(0.3 / 0.07 \mathrm{~mm})$ was inserted intrarectally at $4 \mathrm{~cm}$ from the anus. Trypsin, saline and protease inhibitors were injected into the distal colon through the catheter.

\section{Experimental protocol}

For the assessment of the effect of protease inhibitors on CPP, five groups of Swiss 3T3 mice $(n=8-8)$ received an intracolonic infusion $\left(250 \mu \mathrm{L} \mathrm{h}^{-1}\right)$ of a mixture of water-soluble protease inhibitors with a broad specificity for the inhibition of serine-, cysteine-, asparticand metalloproteases $\left(100 \mu \mathrm{g} \mathrm{mL}^{-1}\right.$, Proteases Inhibitor Cocktail for General Use, Sigma, St Quentin Fallavier,France), cysteine protease inhibitor $\left(100 \mu \mathrm{g} \mathrm{mL}^{-1}\right.$, cystatin, Sigma), serine protease inhibitor $\left(100 \mu \mathrm{g} \mathrm{mL}^{-1}\right.$ aprotinin; Sigmal, matrix metalloprotease inhibitor (100 $\mu \mathrm{g} \mathrm{mL}^{-1}$, galardin, Sigma) or saline for $5 \mathrm{~h}$. Paracellular permeability was assessed during the last $2 \mathrm{~h}$ of protease inhibitor treatment.

Four groups of Swiss 3T3 mice and six groups of C57BL6 mice $(n=8-8)$ were used for studies on antibiotic treatment, respectively. Three groups of Swiss mice and three groups of C57BL6 mice were treated for 12 days with antibiotics $\left(0.5 \mathrm{~g} \mathrm{~L}^{-1}\right.$ ampicillin and $1 \mathrm{~g} \mathrm{~L}^{-1}$ neomycin in drinking water). In preliminary experiments, we verified that these antibiotics had no direct effect on CPP in Ussing chambers (data not shown). One group of Swiss and three groups of C57BL6 mice were used as control. One group of antibiotic treated and one control group of Swiss 3T3 mice were killed at day 12 for the measurement of serine protease activity in colonic luminal contents and immunochemistry of $\mathrm{PAR}_{2}$ in colonic mucosa. In two groups of antibiotic-treated Swiss 3T3 mice, immunochemistry of $\mathrm{PAR}_{2}$ was performed after the animals received daily intracolonically $(50 \mu \mathrm{L})$ trypsin (400 U per mouse) or saline for 2 days under the antibiotic treatment. Two groups of antibiotic-treated and two control groups of C57BL6 mice were killed at day 12 for the in vitro measurement of colonic permeability in Ussing chambers, in basal conditions and after administration of $\mathrm{PAR}_{2}$-activating peptide (SLIGRL) or mast cell degranulator (compound 48/80). Furthermore, one group of antibiotic-treated and one control group of C57BL6 mice were killed at day 12 for the measurement of mouse mast cell protease-1 (MMCP-1) content of colonic mucosa,

\section{Serine protease activity in colonic content}

Colonic content was obtained by rinsing the entire colon with $1 \mathrm{~mL}$ of saline. This solution was transferred to $4 \mathrm{~mL}$ of reaction buffer containing $0.15 \mathrm{~mol} \mathrm{~L}^{-1} \mathrm{NaCl}$ and $20 \mathrm{mmol} \mathrm{L}^{-1}$ Tris-HCL. Coarse particles were removed from this solution by filtration with $0.8-\mu \mathrm{m}$ size syringe filter (Nalgene, Nalge, NY, USA) after centrifugation at $4500 \mathrm{~g}$ for $10 \mathrm{~min}$ at $4{ }^{\circ} \mathrm{C}$. Samples of $25 \mu \mathrm{L}$ from the supernatant 
were incubated with $1 \mathrm{~mL}$ of reaction buffer and $1 \mathrm{~mL}$ of $0.5 \%\left(\mathrm{w} / \mathrm{v}\right.$ ) azocasein (Sigma) at $40^{\circ} \mathrm{C}$ for $20 \mathrm{~min}$. The reaction was stopped by the addition of $1 \mathrm{~mL}$ of $10 \%(\mathrm{w} / \mathrm{v})$ trichloroacetic acid (TCA; Sigma). After centrifugation at $4500 \mathrm{~g}$ for $10 \mathrm{~min}$ at $4{ }^{\circ} \mathrm{C}$, absorption of the clear supernatant was measured at $366 \mathrm{~nm}$ and compared with standard curves obtained from a titration series of azocasein. The protein content of the filtered supernatant of colonic content was assessed with BCA-200 Protein Assay Kit (Pierce, Rockford, IL, USA), with bovine serum albumin (BSA) as a standard. Serine protease activity was expressed as units of trypsin activity in $\mathrm{mg}$ of total proteins $\left(\mathrm{U} \mathrm{mg}^{-1}\right)$.

\section{Immunohistochemistry of $\mathbf{P A R}_{2}$}

Colonic samples were fixed $12 \mathrm{~h}$ in $4 \%$ formalin, dehydrated through graded ethanol and embedded in paraffin. Sections $(5 \mu \mathrm{m})$ were rehydrated and submerged in antigen retrieval solution (citrate buffer, $10 \mathrm{mmol} \mathrm{L}-1, \mathrm{pH} 6,95^{\circ} \mathrm{C}, 3 \mathrm{~min}$ ). After inhibition of endogenous peroxydases with $0.6 \% \mathrm{H}_{2} \mathrm{O}_{2}$ in $100 \%$ methanol for $30 \mathrm{~min}$ and incubation in blocking solution (phosphate buffered saline (PBS) containing $1 \%$ BSA and $2 \%$ goat normal serum), sections were incubated with rabbit $\mathrm{PAR}_{2}$ antibody (supplied by $\mathrm{M}$. D. Hollenberg) (overnight, $+4^{\circ} \mathrm{C}$ ) followed by a biotinylated goat anti-rabbit IgG immune serum $130 \mathrm{~min}$, room temperature) and subsequently with avidinbiotin complex complexes coupled to peroxydase (Vectastain Elite ABC kit; AbCys, Paris, France). Antigen-antibody complexes were revealed using 3-3'-diaminobenzidine (DAB kit; ICN Pharmaceuticals, Costa Mesa, CA, USA). Hemalum was used as a counterstain. As negative controls, sections were treated with the same procedure except for the absence of primary antibody.

\section{Immunohistochemical analysis}

Immunohistochemical analysis was performed in a blinded fashion using a Nikon $90 \mathrm{i}$ microscope. $\mathrm{PAR}_{2}$ expression was quantified employing the software LUCIA G (version 4.8, Nikon, Champigny-sur-Marne, France) measuring the mean density per square micrometre of colonic epithelium. All analyses were performed on 10fields per sample.

\section{In vivo permeability studies}

Mice were anaesthetized with xylazine/ketamine 110 and $2 \mathrm{mg}$ per mouse, respectively; subcutaneously). To measure CPP, $0.7 \mu \mathrm{Ci}$ of ${ }^{51} \mathrm{Cr}$-EDTA (Perkin Elmer Life
Sciences, Paris, France) in $0.5 \mathrm{~mL} \mathrm{NaCl} 0.9 \%$ was slowly infused into the colon $\left(2 \mathrm{~h}, 0.25 \mathrm{~mL} \mathrm{~h}^{-1}\right)$. After $2 \mathrm{~h}$, mice were killed by cervical dislocation and colons were removed. Colons and remaining bodies were then placed in separate counting tubes in a gamma-counter (Packard Cobra II; Packard Bioscience, Meriden, CT, USA). The permeability was expressed as the ratio between body and total (body plus colon) radioactivities.

\section{In vitro permeability studies}

C57BL6 mice were killed by cervical dislocation. The distal colon was removed and two colonic strips from each mouse were mounted in Ussing-type chambers (Easymount, Hamden, CT, USA) having a flux area of $0.3 \mathrm{~cm}^{2}$. Both sides of each colonic sheet were bathed in $5 \mathrm{~mL}$ of Krebs solution which was maintained at $37^{\circ} \mathrm{C}$ and oxygenated continuously with $5 \% \mathrm{CO}_{2}$ in $\mathrm{O}_{2}$. Permeability was assessed by measuring mucosal to serosal fluxes of fluorescein isothiocyanate (FITC)dextran across the colonic strip. For the assessment of $\mathrm{PAR}_{2}$ responsiveness, the FITC-dextran flux was determined $1 \mathrm{~h}$ after the administration of SLIGRL or its vehicle (saline). For the measurement of the effect of mast cell degranulation, the FITC-dextran flux was evaluated $1 \mathrm{~h}$ after the administration of compound $48 / 80$ or its vehicle (water). In brief, after a 20 min equilibrium period $550 \mu \mathrm{L}$ of buffer solution on the mucosal side was replaced by $500 \mu \mathrm{L}$ of FITCDextran (10000 MW, $0.022 \mathrm{~g}$ ) and $50 \mu \mathrm{L}$ of SLIGRL (25 $\left.\mu \mathrm{mol} \mathrm{L}^{-1}\right)$, saline, compound $48 / 80\left(10 \mu \mathrm{g} \mathrm{mL}^{-1}\right)$ or water. After 30 and $60 \mathrm{~min}, 800 \mu \mathrm{l}$ solution from the serosal side was removed and fluorescence was measured on fluorimeter (Luminescence Spectrometer LS 50 B; Perkin Elmer, Wellesley, MA, USA). The FITCdextran flux was expressed as quantity of FITC-dextran that crossed $1 \mathrm{~cm}^{2}$ in $1 \mathrm{~h}\left(\mathrm{nmol} \mathrm{h} \mathrm{h}^{-1} \mathrm{~cm}^{-2}\right)$.

\section{ELISA for MMCP-1}

C57BL6 mice were killed by cervical dislocation. The distal colon was removed and the colonic mucosa was carefully removed with a dissector. The mucosal samples were homogenized in RIPA buffer (Roche Diagnostics, Basel, Switzerland) and centrifuged at $10000 \mathrm{~g}$ at $4{ }^{\circ} \mathrm{C}$. Supernatants were used for the MMCP-1 and total protein content measurements. MMCP-1 ELISA assays were performed with MMCP-1 ELISA Kit (Moredun, Midlothian, UK). Dynatech M129B 96-well plates (Dynatech, Plochingen, Germany) were coated for $24 \mathrm{~h}$ at $4{ }^{\circ} \mathrm{C}$ with $2 \mu \mathrm{g} / \mathrm{mL}$ of affinity-purified sheep antiMMCP-1 Ig in carbonate buffer $(\mathrm{pH} 9.6)$. Wells were washed $|6 \times|$ with PBS and $0.05 \%(v / v)$ Tween 20 . 
Standards $\left(0.25-12 \mathrm{ng} \mathrm{mL} \mathrm{m}^{-1}\right.$ of purified MMCP-1) and samples were applied $(50 \mu \mathbf{L}$ per well $)$, diluted as appropriate in PBS containing 4\% BSA and $0.05 \%(\mathrm{v} / \mathrm{v})$ Tween 20. After incubation in room temperature for $1.5 \mathrm{~h}$, plates were washed as above and incubated for $1 \mathrm{~h}$ at room temperature with $50 \mu \mathrm{L}$ per well of rabbit antiMMCP-1-horseradish peroxidase conjugate [diluted as appropriate in PBS containing $4 \%$ BSA and $0.05 \%(\mathrm{v} / \mathrm{v})$ Tween 20]. Plates were washed and incubated for $25 \mathrm{~min}$ at room temperature with $50 \mu \mathrm{L}$ per well ortho-phenylene diamine $/ \mathrm{H}_{2} \mathrm{O}_{2}$ substrate. The reaction was stopped with $25 \mu \mathrm{L}$ per well $2.5 \mathrm{~mol} \mathrm{~L}^{-1} \mathrm{H}_{2} \mathrm{SO}_{4}$. Plates were read at $492 \mathrm{~nm}$ on Microplate Reader. The standard curve was generated and sample concentrations were calculated using software (Microplate Manager 5.2.1, Bio-Rad, Marnes-La-Coquette, France). Protein concentration was determined with a commercial kit (BCA-200 Protein Assay Kit; Piercel MMCP-1 content of colonic mucosa was expressed as ng of MMCP per gram of total proteins.

\section{Chemicals}

SLIGRL-NH2 prepared by solid-phase synthesis was obtained from Neosystem (Strasbourg, France). The composition and purity of peptides were confirmed by HPLC analysis. Trypsin, neomycin sulphate, compound $48 / 80$, the mixture of serine protease inhibitors [Protease Inhibitor Cocktail for General Use containing 4-(2-aminoethyl)-benzenesulphonyl-fluoride, E-64, bestatin, leupeptin, aprotinin, Na-EDTA], cysteine protease inhibitor /cystatin from chicken egg white lyophilized powder|, serine protease inhibitor (aproti$\mathrm{nin}$ ) and the matrix metalloprotease inhibitor galardin, $N$-[(2S)-(methoxycarbonylmethyl)-4-methylpentanoyl]L-tryptophan-methylamide were obtained from Sigma. Ampicillin was obtained from Euromedex (Souffelveyerstein, France). SLIGRL was dissolved in saline, compound $48 / 80$ was dissolved in distilled water, neomycin and ampicillin were dissolved in tap water.

\section{Statistical analysis}

Data are presented as means \pm standard error of the mean. Analyses were carried out by running the GraphPad Prism 4.0 software (GraphPad, San Diego, CA, USA). All data were normally distributed. Between-group comparisons were performed by Student's unpaired $t$-test. Multiple comparisons within groups were performed by repeated measures one-way ANOVA, followed by Student's $t$-test. Statistical significance was accepted at $P<0.05$.

\section{RESULTS}

\section{In vivo gut paracellular permeability}

In anaesthetized mice, basal gut permeability measured for $2 \mathrm{~h}$ after intracolonic saline administration was $2.2 \pm 0.1 \%$ of total ${ }^{51} \mathrm{Cr}$-EDTA recovered. Intracolonic administration of mixture of antiproteases reduces this basal value to $1.1 \pm 0.2 \%$. Aprotinin, a serine protease inhibitor, reduced the basal colonic permeability to $1.1 \pm 0.1 \%$. Galardin, a matrix metalloprotease inhibitor, significantly decreased CPP compared with saline perfusion $\{0.9 \pm 0.2 \%$ vs $2.2 \pm 0.1 \%)(P<0.01\}$. In contrast, only cystatin, a cysteine protease inhibitor, had no effect on CPP $(2.1 \pm 0.2 \%)$ (Fig. 1$)$.

In mice treated with antibiotics during 12 days, the CPP was not significantly changed when compared with control animals $(1.1 \pm 0.1 \%$ vs $1.0 \pm 0.1 \%)$ (Fig. 2$)$.

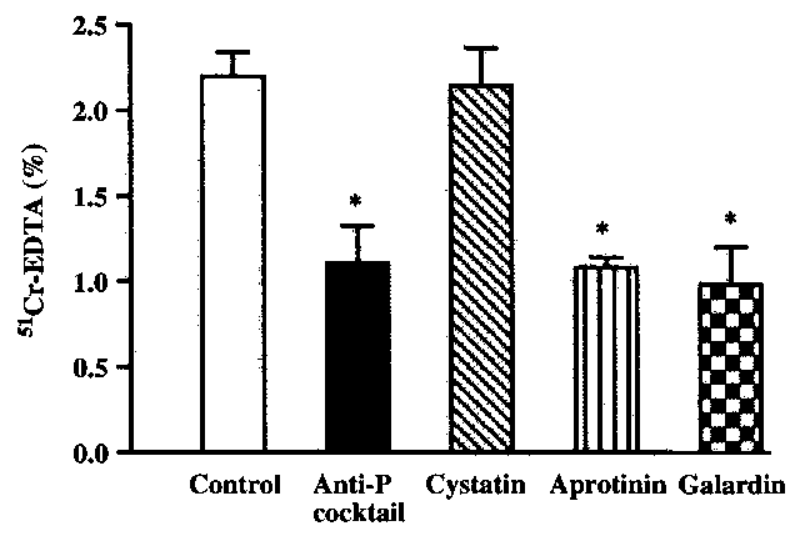

Figure 1 Effect of intracolonic infusion of antiprotease cocktail, selective cysteine- (cystatin), serine- (aprotinin) and matrix metalloprotease inhibitors (galardin) on colonic paracellular permeability. Inhibitors were infused at a dose $50 \mu \mathrm{g}^{2} \mathrm{~h}^{-1}$ per mouse. Values are means \pm SEM. ${ }^{\star} P<0.01$, significantly different from controls [saline infusion).

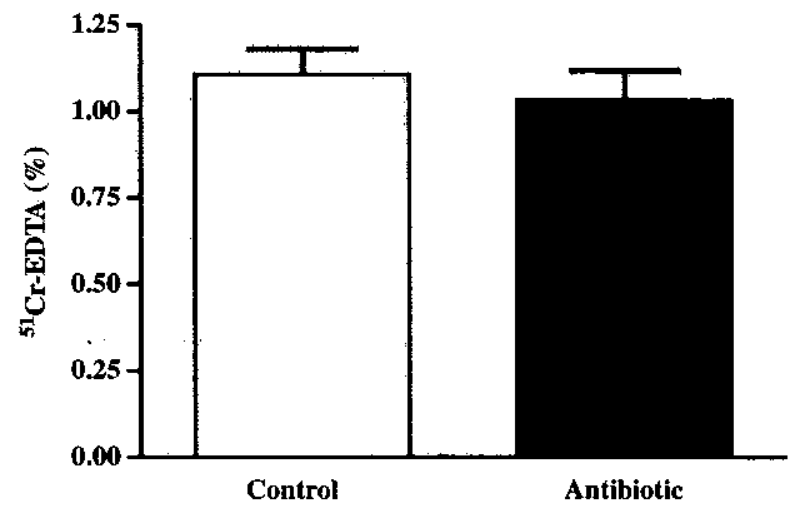

Figure 2 Effect of antibiotic treatment on colonic paracellular permeability (in vivo). Values are means \pm SEM.

(C) 2006 The Authors 


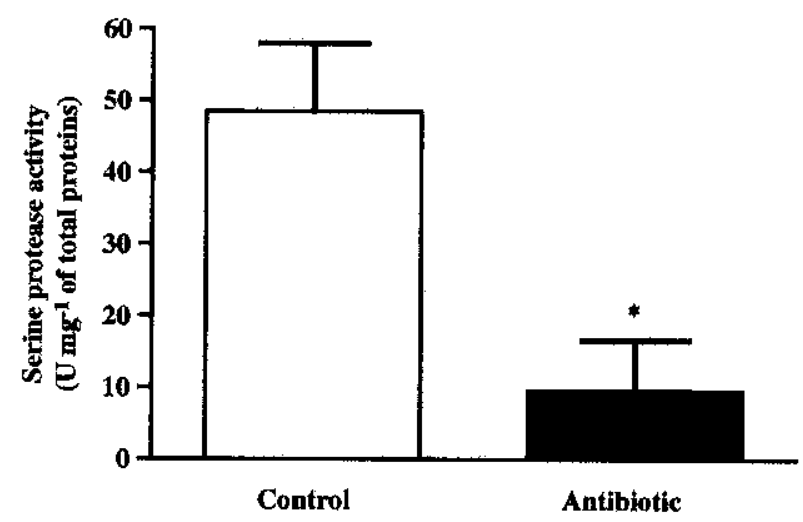

Figure 3 Effect of antibiotic treatment on serine protease activity of colonic content. Values are means \pm SEM.

${ }^{\star} P<0.01$, significantly different from non-treated controls.

\section{Serine protease activity of colonic contents}

In fasted control Swiss mice, the serine protease activity of colonic content was $48.4 \pm 9.5 \mathrm{U} \mathrm{mg}^{-1}$ of total proteins. A oral antibiotic treatment for 12 days reduced the serine protease activity of colonic content to $9.6 \pm 7.0 \mathrm{U} \mathrm{mg}^{-1}$ of total proteins $(P<0.01)$ (Fig. 3).

\section{PAR $_{2}$ immunohistochemistry}

Basal $\mathrm{PAR}_{2}$ immunochemistry showed prominent immunostaining of colonocytes loptical density: $0.3 \pm 0.1$. In antibiotic-treated mice, $\mathrm{PAR}_{2}$ immunostaining was significantly attenuated (optical density: $0.2 \pm 0.1)$ when compared with control animals $(P<0.01)$. Under antibiotic treatment, 2 days of daily intracolonic administration of trypsin restored the $\mathrm{PAR}_{2}$ immunoreactivity (optical density: $0.3 \pm 0.1$ ) (Fig. 4A,B).

\section{In vitro gut permeability}

Control values of dextran sulphate flux significantly increased after the application of $\mathrm{PAR}_{2}$ agonist, SLIGRL to the mucosal site $(1.4 \pm 0.5$ vs $\left.4.1 \pm 0.7 \mathrm{nmol} \mathrm{h}^{-1} \mathrm{~cm}^{-2} ; P<0.05\right)$. Colonic strips collected from animals treated with antibiotics exhibit dextran sulphate flux similar to that observed in strips collected from controls $\left(1.4 \pm 0.1 \mathrm{nmol} \mathrm{h}^{-1} \mathrm{~cm}^{-2}\right)$; however, antibiotic treatment for 12 days significantly reduced the effect of SLIGRL on colonic permeability $\left(2.1 \pm 0.4 \mathrm{nmol} \mathrm{h}^{-1} \mathrm{~cm}^{-2}\right)$ (Fig. 5). Administration of compound $48 / 80$ resulted in a significantly higher increase $(P<0.05)$ in colonic permeability in control animals $\quad\left[5.9 \pm 0.6 \quad\right.$ vs $\quad 1.9 \pm 0.3 \mathrm{nmol} \mathrm{h}^{-1} \mathrm{~cm}^{-2}$; $P<0.01)$ when compared with the antibiotic-treated mice $\left\{3.6 \pm 0.4\right.$ vs $\left.2.2 \pm 0.3 \mathrm{nmol} \mathrm{h}^{-1} \mathrm{~cm}^{-2} ; P<0.05\right\}$ (Fig, 6).

\section{MMCP-1 content of colonic mucosa}

In control mice, the MMCP-1 content of colonic mucosa was $4.6 \pm 0.7 \mathrm{ng} \mathrm{g}^{-1}$ of total proteins. After 12 days of antibiotic treatment, MMCP-1 content was not significantly changed $14.1 \pm 0.9 \mathrm{ng} \mathrm{g}^{-1}$ of total proteins) when compared with control values (Fig. 7).

\section{DISCUSSION}

This study provides new evidence that luminal proteases regulate CPP in physiological conditions and that colonic microflora affects colonocyte $\mathrm{PAR}_{2}$ expression possibly through luminal protease activity. We also evidence that colonic bacterial flora influences mucosal mast cell degranulation, but not the release of mast cell protease into the colonic lumen, suggesting a limited role of secreted proteases from mast cells in the regulation of epithelial cell $\mathrm{PAR}_{2}$ expression probably regulated only by luminal proteases.

Protease-activated receptors are highly expressed in the gastrointestinal tract. Among others, they are present in colonic epithelial cells. Proteases from endogenous or bacterial origin can activate PARs. Trypsin and trypsinogen released from digestive glands and epithelial cells, ${ }^{1,12}$ thrombin, factors VIIa and Xa from coagulation cascade $\mathrm{e}^{13,14}$ and cathepsin $G$, elastase or proteinase 3 released from neutrophils ${ }^{15,16}$ are potential activators of PARs. Bacteria have both protease and antiprotease activity. Indeed, Porphyromonas gingivalis, a pathogen bacterium in the oral cavity, a mediator of periodontal disease, releases arginine-specific protease (gingipain) which can activate $\mathrm{PAR}_{1}$, $\mathrm{PAR}_{2}$ and $\mathrm{PAR}_{4} .^{9-11}$ Clinical studies have shown an elevated colonic protease activity ${ }^{17}$ and overexpression of colonic $\mathrm{PAR}_{2}$ in patients with $\mathrm{IBD} .^{7}$ These recent observations support a role of colonic protease activity and $\mathrm{PAR}_{2}$ in intestinal inflammation, however, until now, the physiological role of intraluminal proteases and $\mathrm{PAR}_{2}$ in the control of colonic barrier function has been unexplored.

In a previous study, we have shown that low dose of SLIGRL infused intracolonically activated $\mathrm{PAR}_{2}$ and increased paracellular permeability to macromolecules in vivo through calmodulin and subsequent MLCK activation provoking tight junction opening by perijunctional ring myosin phosphorylation. ${ }^{14}$ Intracolonic administration of higher dose of SLIGRL also caused 
$\mathbf{A}$
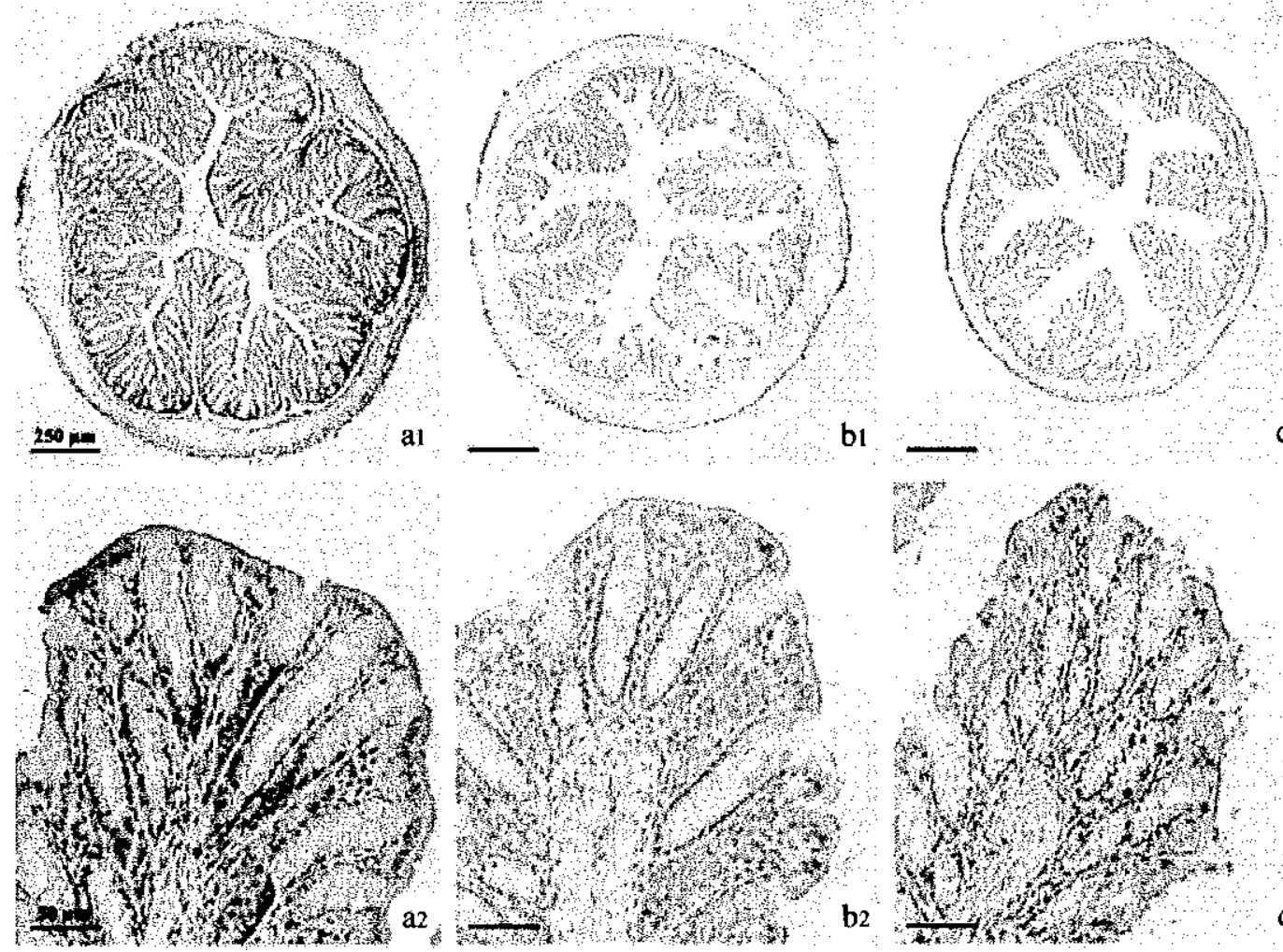

1

$\mathrm{c} 1$
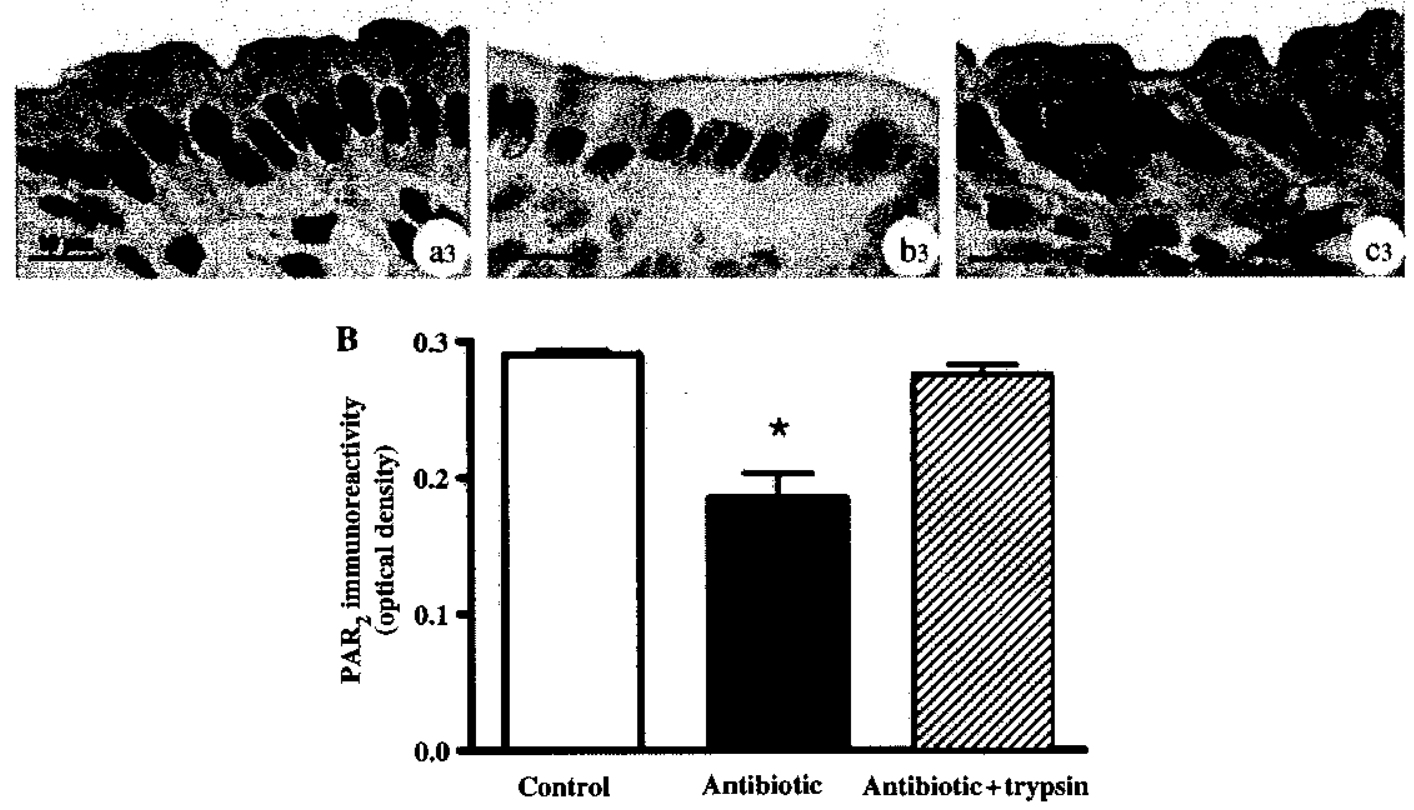

Figure 4 (A) Effect of antibiotic treatment on colonic protease activated receptor-2 (PAR $)$ immunostaining. PAR $_{2}$ immunoreactivity (brown) in colonic sections of control animals $\{\mathrm{a} 1, \mathrm{a} 2, \mathrm{a} 3\}$, antibiotic treated animals $(\mathrm{b} 1, \mathrm{~b} 2, \mathrm{~b} 3)$ and animals received daily intracolonic trypsin injections during the antibiotic treatment (c1, c2, c3). (B) Effect of antibiotic treatment on colonic PAR 2 immunohistochemistry. Data (means \pm SEM) are expressed as total number of grey levels per square micrometre of colonic mucosa. ${ }^{*} P<0.01$, significantly different from control mice and animals received daily intracolonic trypsin injections during the antibiotic treatment. 


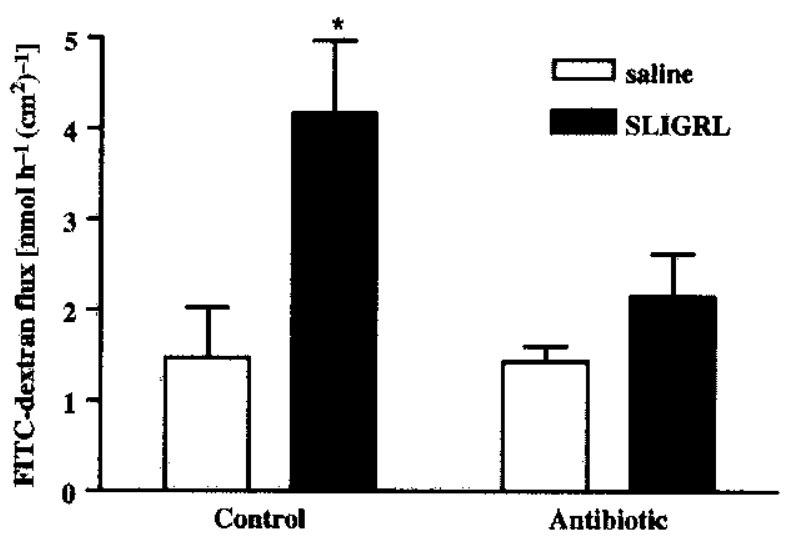

Figure 5 Basal fluorescein isothiocyanate-dextran flux and the effect of SLIGRL on colonic permeability after antibiotic treatment. Values are means $\pm \mathrm{SEM},{ }^{\star} p<0,05$, significantly different from non-treated controls.

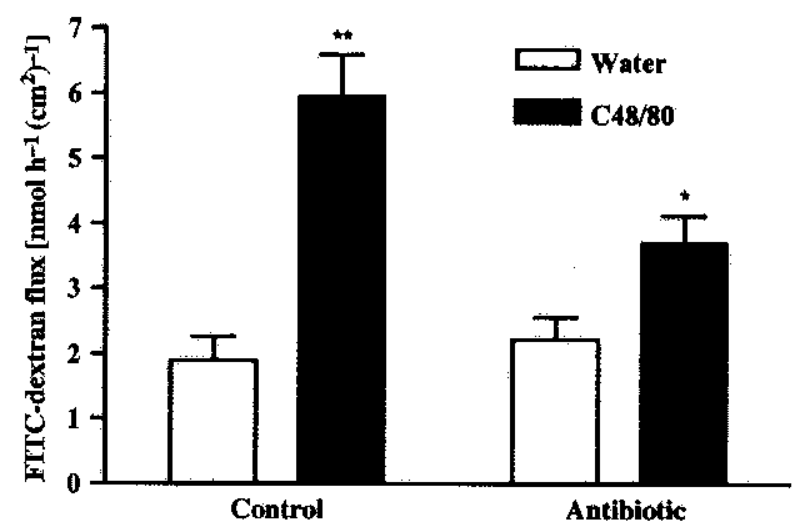

Figure 6 Basal fluorescein isothiocyanate-dextran flux and the effect of compound $48 / 80$ on colonic permeability after antibiotic treatment. Values are means \pm SEM. ${ }^{*}{ }^{\star} P<0,01$, significantly different from non-treated controls. ${ }^{\star} P<0.05$, significantly different from antibiotic treated controls and C48/80 group of non-treated animals.

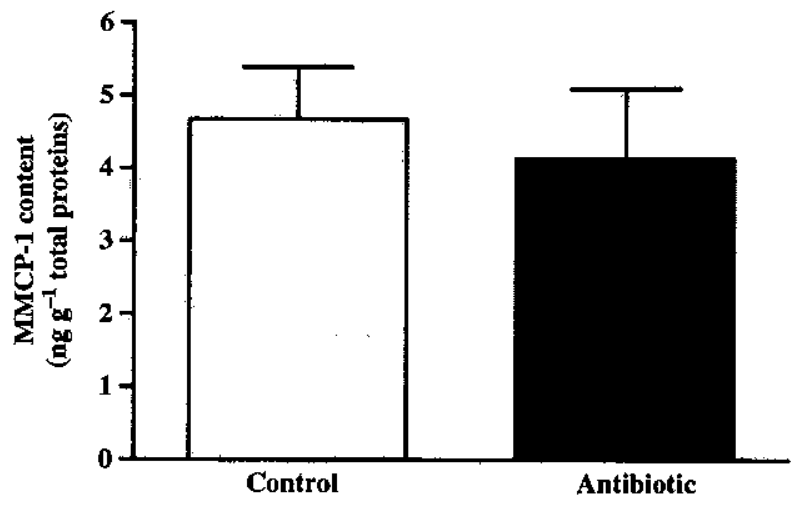

Figure 7 Mouse mast cell proteinase- 1 content in the colonic mucosa after antibiotic treatment. Values are means \pm SEM. colonic inflammation partly independently of paracellular permeability. Mast cell serine proteases, ${ }^{18}$ neutrophil serine proteases ${ }^{19}$ and Bacteroides fragilis metalloprotease $^{20}$ are known to increase intestinal permeability. However colonic digestive enzymes are potent activators of $\mathrm{PAR}_{2}^{1,12}$ and although intracolonic administration of selective $\mathrm{PAR}_{2}$ agonist increases $\mathrm{CPP},{ }^{3,4}$ no studies have already reported the physiological effect of digestive enzymes on colonic barrier function. Our study is the first to investigate the effect of different luminal proteases on colonic barrier function. We have shown that intraluminal delivery of protease inhibitors decreases CPP.

In the colon, resident bacteria release serine proteases, and other proteases and the digestive enzymes are partly degraded by host-proteases and bacterial peptide hydrolases. ${ }^{21,22}$ Therefore, the pathogenic and nonpathogenic bacteria are considerably responsible for the luminal proteolytic activity. Although substantial proportion of colonic intestinal proteases is of bacterial origin, no evidence reported about the effect of colonic bacteria on PAR function. We demonstrated that the reduction of resident colonic bacteria by antibiotic treatment decreases the serine protease activity of the colonic content coupled with a decrease in $\mathrm{PAR}_{2}$ expression in colonic mucosa. The effect on $\mathrm{PAR}_{2}$ expression is specific for the protease activity of the colonic content, because daily colonic administration of a serine protease restores $\mathrm{PAR}_{2}$ expression of colonocytes. However, in contrast to that observed with serine protease inhibitors, we did not find any significant change in colonic paracellular permeability after broad-spectrum antibiotic treatment, despite the downregulation of $\mathrm{PAR}_{2}$ and the reduced protease activity. A possible explanation for this phenomenon is that changes in $\mathrm{PAR}_{2}$ expression and in protease activity occur slowly during the 12 days of treatment given rise to compensatory mechanism regulating CPP.

Tryptase released from mast cells may activate $\mathrm{PAR}_{2}$ located on epithelial cells directly on basolateral site. ${ }^{23}$ Increased mast cell tryptase release was found in colonic biopsies proven from ulcerative colitis patients ${ }^{24}$ moreover, increased mast cell density was observed in colonic biopsy specimens of IBS patients, ${ }^{25-27}$ and supernatant from colonic biopsies of IBS patients injected into paw of rats induced sensitization to pressure stimulus through $\mathrm{PAR}_{2}$ activation. ${ }^{8}$ Although mast cells localized in close contact with the external environment play an important role in the response to pathogen intestinal bacteria, ${ }^{28,29}$ the effect of non-pathogen resident intestinal microorganisms on mast cell function is not clear. We 
found that changes in resident bacterial flora following oral antibiotic treatment decreased colonic mast cell degranulation; however, colonic mucosal mast cell proteinase-1 content remained unchanged. Through the bidirectional cross-talk between mast cells and $\mathrm{PAR}_{2}$, the explanation of decreased mast cell degranulation after the modification of colonic flora could be dual. The decreased sensitivity of mast cells to degranulate related to changes in colonic bacterial stimulation could result from a decrease in $\mathrm{PAR}_{2}$ expression of colonocytes; however, the decrease of mast cell degranulation could be the result of decreased $\mathrm{PAR}_{2}$ responsiveness of mast cells mediated by change of colonic luminal protease activity.

Intestinal permeability plays a key role in the pathogenesis of different gastrointestinal disorders. Increased intestinal permeability has been described in patients with Crohn's disease, ${ }^{30}$ and in symptomfree, healthy relatives of Crohn's disease patients. ${ }^{31}$ Increased intestinal permeability is also a predictor of relapse in patients with Crohn's disease. ${ }^{32}$ Postinfectious IBS is also associated with an increase in intestinal permeability. ${ }^{33}$ Alterations of visceral sensitivity provoked by acute partial restraint stress depends upon the increase in CPP. ${ }^{34}$ Similarly, intracolonic infusion of subinflammatory doses of $\mathrm{PAR}_{2}$ agonist produces a delayed rectal hyperalgesia that involves an increase in intestinal permeability in rats. ${ }^{35}$ Our study showed that colonic serine proteases regulate CPP supporting the hypothesis that a high level of intraluminal proteases may play a role in the development of colonic inflammation and visceral hyperalgesia.

Finally, our data indicate that luminal proteases regulate CPP in physiological conditions and modification of colonic bacterial flora affects colonocyte $\mathrm{PAR}_{2}$ expression and sensitivity of mast cells to degranulate. Therefore, it leads us to speculate that changes in intraluminal protease activity linked to alterations of colonic microflora and/or proteolytic enzyme secretion may play a role in the genesis of visceral hypersensitivity and IBS symptoms.

\section{ACKNOWLEDGMENTS}

This work was supported by the Institut National de Recherce Agronomique (Paris, France).

\section{REFERENCES}

1 Nystedt S, Lanson AK, Aberg H, Sundelin J. The mouse proteinase-activated receptor- 2 cDNA and gene. Molecular cloning and functional expression. I Biol Chem 1995, 270: 5950-5.
2 Kong W, McConalogue K, Khitin LM et al, Luminal trypsin may regulate enterocytes through proteinase-activated receptor 2. Proc Natl Acad Sci U S A 1997, 94: 8884-9.

3 Cenac N, Coelho AM, Hguyen C et al. Induction of intestinal inflammation in mouse by activation of proteinaseactivated receptor-2. Am J Pathol 2002; 161: 1903-15.

4 Cenac N, Chin AC, Garcia-Villar R et al, PAR2 activation alters colonic paracellular permeability in mice via IFN- $\gamma$ dependent and -independent pathways. I Physiol 2004, 558: $913-25$.

5 Cenac N, Garcia-Villar R, Ferrier L et al. Proteinase-activated receptor-2-induced colonic inflammation in mice: possible involvement of afferent neurons, nitric oxide, and paracellular permeability. I Immunol 2003; 170: 4296-300.

6 Nguyen C, Coelho AM, Grady EF et al. Proteinase-activated receptor-2-induced colitis is mediated by a neurogenic mechanism. Can I Physiol Pharmacol 2003; 81: 920-7.

7 Kim JA, Choi SC, Yun KJ et al. Expression of proteaseactivated receptor 2 in ulcerative colitis. Inflamm Bowel Dis 2003; 9: 224-9.

8 Vergnolle N, Shhaffer E, Andrews C. Role for proteases and protease-activated receptor- 2 in hyperalagaesia induced by supernatants of IBS patients biopsies. Neurogastroenterol Motil 2004, 16: 848A

9 Lourbakos A, Chinni C, Thompson P et al. Cleavage and activation of proteinase-activated receptor-2 on human neutrophils by gingipain- $\mathrm{R}$ from Porphyromonas gingivalis. FEBS Lett 1998; 435: 45-8.

10 Lourbakos A, Yuan Y, Jenkins AL et al. Activation of protease-activated receptors by gingipains from Porphyromonas gingivalis leads to platelet aggregation: a new trait in microbial pathogenicity. Blood 2001; 97: 3790-7.

11 Lourbakos A, Potempa J, Travis J et al. Arginine-specific protease from Porphyromonas gingivalis activates protease-activated receptors on human oral epithelial cells and induces interleukin-6 secretion. Infect Immun 2001; 69: 5121-30.

12 Nystedt S, Emilsson K, Wahlestedt C, Sundelin J. Molecular cloning of a potential proteinase activated receptor. Proc Natl Acad Sci U S A 1994; 91: 9208-12.

13 Camerer E, Huang W, Coughlin SR. Tissue factor- and factor X-dependent activation of protease-activated receptor 2 by factor VIla. Proc Natl Acad Sci U S A 2000, 97: 5255-60.

14 Riewald M, Ruf W. Mechanistic coupling of protease signalling and initiation of coagulation by tissue factor. Proc Natl Acad Sci U S A 2001, 98: 7742-7.

15 Uehara A, Sugawara S, Muramoto K, Takada H, Activation of human oral epithelial cells by neutrophil proteinase 3 through protease-activated receptor-2. I Immunol 2002; 169: 4594-603.

16 Uehara A, Muramoto K, Takada H, Sugawara S. Neutrophil serine proteinases activate human nonepithelial cells to produce inflammatory cytokines through proteaseactivated receptor 2. I Immunol 2003; 170: 5690-6.

17 Bustos D, Negri G, De Paula JA et al. Colonic proteinases: increased activity in patients with ulcerative colitis. Medicina (B Aires) 1998, 58: 262-4.

18 King SJ, Miller HRP. Mast cell serine protease release increased intestinal permeability in model of hypersensitivity in Nippostrongylus-primed rats. Immunology 1984; 51: 653-9.

(c) 2006 The Authors Journal compilation (ㄷ) 2006 Blackwell Publishing Ltd 
19 Zhang Z, Yan L, Wang L et al. Entamoeba histolytica cysteine proteinases with interleukin-1 beta converting enzyme (ICE) activity cause intestinal inflammation and tissue damage in amoebiasis. Mol Microbiol 2000; 37: 542-8.

20 Wells CL, van de Westerlo EM, Jechorek RP, Feltis BA, Wilkins TD, Ermandsen SL. Bacteroides fragilis enterotoxin modulates epithelial permeability and bacterial internalisation by HT-29 enterocytes. Gastroenterology 1996; 110: 1429-37.

21 Macfarlane GT, Allison C, Gibson SA, Cummings IH. Contribution of the microflora to proteolysis in the human large intestine. / Appl Bacteriol 1988; 64: 37-46.

22 Bischoff SC, Wedemeyer J, Herrmann A et al. Quantitative assessment of intestinal eosinophils and mast cells in inflammatory bowel disease. Histopathology 1996, 28 : 1-13.

23 Grady EF, Yang P, Amadesi $S$ et al. Mast cells induce epithelial barrier disfunction by activatrion of protease activated receptor 2 (PAR2). Gastroenterology 2004; 12: 519 A.

24 Raithel M, Winterkamp S, Pacurar A, Ulrich P, Hochberger J, Hahn EG. Release of mast cell tryptase from human colorectal mucosa in inflammatory bowel disease. Scand I Gastroenterol 2001; 36: 174-9.

25 Nishida $\mathrm{Y}$, Murase $\mathrm{K}$, Isomoto $\mathrm{H}$ et al. Different distribution of mast cells and macrophages in colonic mucosa of patients with collagenous colitis and inflammatory bowel disease. Hepatogastroenterology 2002; 49: 678-82.

$26 \mathrm{O}^{\prime}$ Sullivan M, Clayton N, Breslin NP et al. Increased mast cell in the irritable bowel syndrome. Neurogastroenterol Motil 2000, 12: 449-57.

27 Barbara G, Stanghellini V, DiGiorgio R et al. Activated mast cells in proximity to colonic nerves correlate with abdominal pain in irritable bowel syndrome. Gastroenterology 2004, 126: 693-702.

28 Pulimood AB, Mathan MM, Mathan VI, Quantitative and ultrastructural analysis of rectal mucosal mast cells in acute infectious diarrhea. Dig Dis Sci 1998, 43: 2111-6.

29 Aschenbach IR, Seidler T, Ahrens $F$ et al. Luminal salmonella endotoxin affects epithelial and mast cell function in the proximal colon of pigs. Scand / Gastroenterol 2003; 38: 719-26.

30 Teahon K, Smethurst P, Levi AJ, Menzies IS, Bjarnason I. Intestinal permeability in patients with Crohn's disease and their first degree relatives. Gut 1992; 33: 320-3.

31 Peeters M, Geypens B, Claus D et al. Clustering of increased small intestinal permeability in families with Crohn's disease. Gastroenterology 1997, 113: 802-7.

32 Jorgensen J, Ranlov PI, Bjerrum PJ, Diemer H, Bisgaard K, Elsborg L. Is an increased intestinal permeability a valid predictor of relapse in Crohn's disease? Scand / Gastroenterol 2001, 36: 521-7.

33 Marshall JK, Thabane M, Garg AX, Clark W, Meddings J, Collins SM. Intestinal permeability in patients with irritable bowel syndrome after a waterborne outbreak of acute gastroenteritis in Walkerton, Ontario. Aliment Pharmacol Ther 2004; 20: 1317-22.

34 Ait-Belgnaoui A, Bradesi S, Fioramonti J, Theodon V, Bueno L. Acute stress-induced hypersensitivity to colonic distension depends upon increase in paracellular permeability: role of myosin light chain kinase. Pain 2005; 113: $141-7$.

35 Coelho AM, Vergnolle N, Guiard B, Fioramonti J, Bueno L. Proteinases and proteinase-activated receptor 2 : a possible role to promote visceral hyperalgesia in rats. Gastroenterology 2002; 122: 1035-47. 
